SANDIA REPORT

SAND96-0923 - UC-704

Unlimited Release

Printed April 1996
RECEIVED

MAY 151996

Q.8.

\title{
Ceramic Powder Synthesis in Supercritical Fluids
}

C. L. J. Adkins, E. M. Russick, J. Cesarano, M. E. Tadros, J. A. Voigt

Prepared by

Sandia National Laboratories

Albuquerque, New Mexico 87185 and Livermore, California 94550

for the United States Department of Energy

under Contract DE-AC04-94AL85000

Approved for public release; distribution is unlimited.

Widituris:
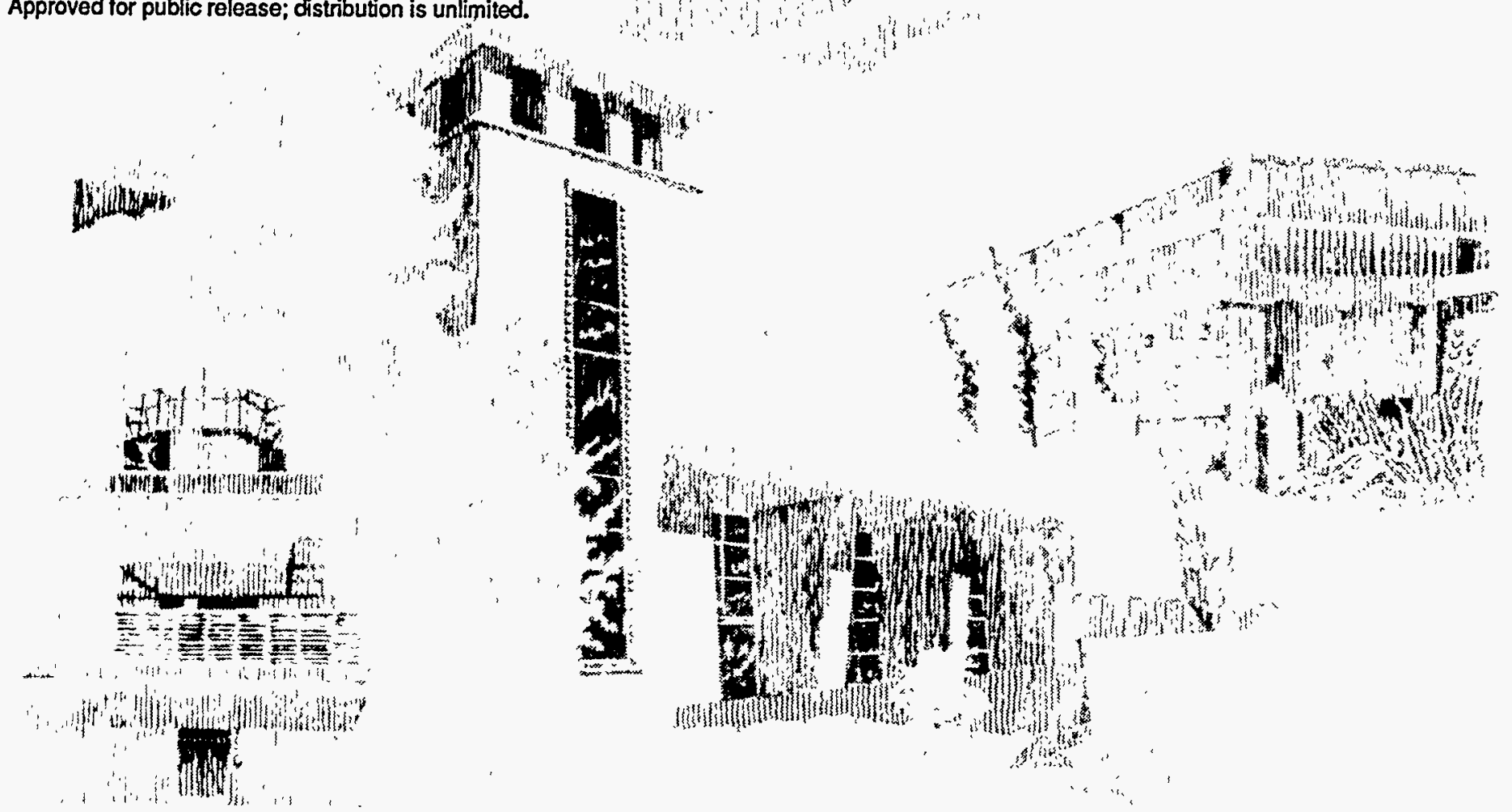

$\operatorname{ain}$

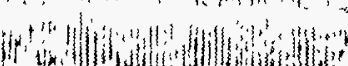

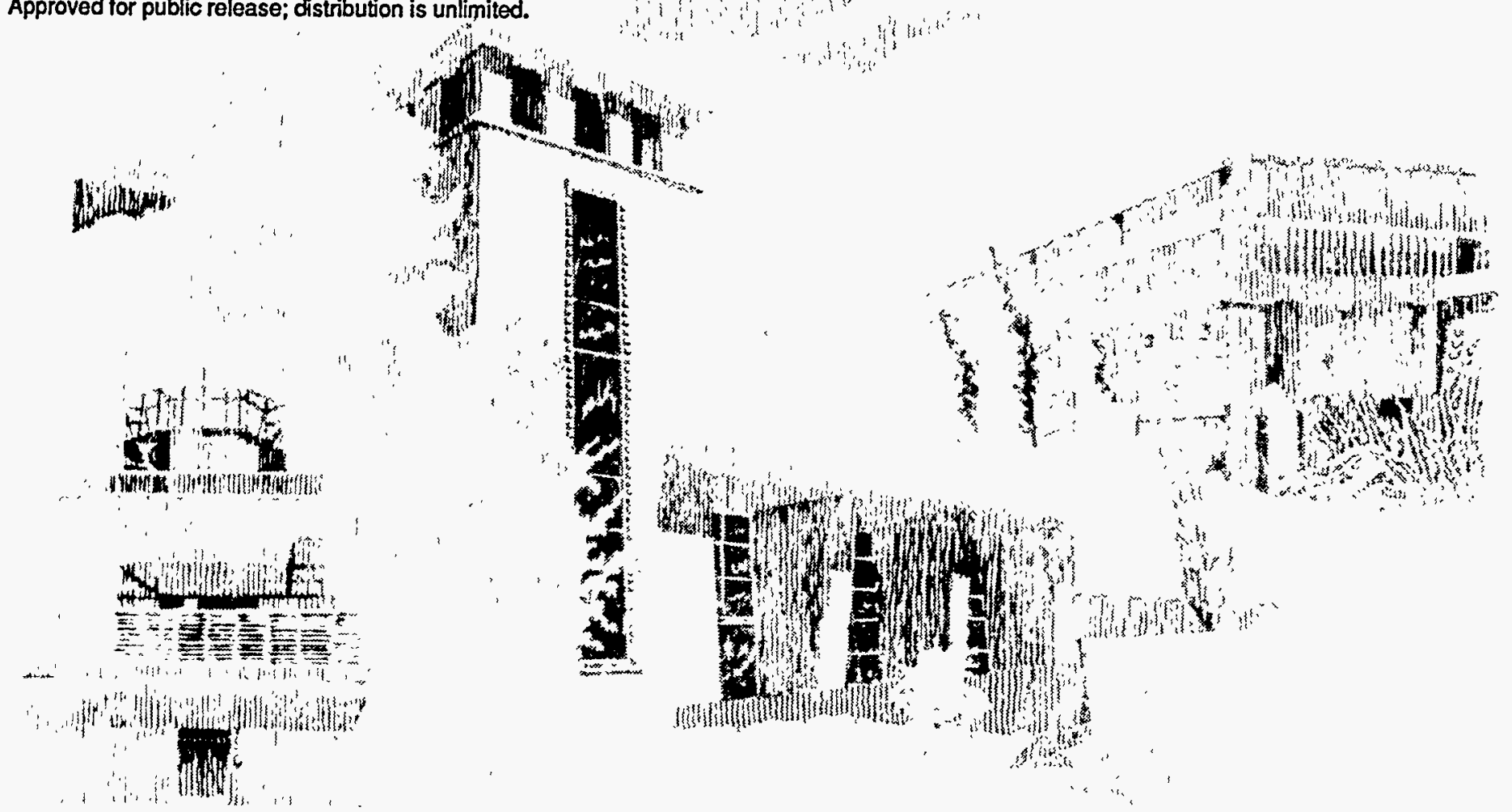

$4-17$

SF29000(8-81)

DISTRIBITION OF THIS DOCUMENT IS UNLIMITED 
Issued by Sandia National Laboratories, operated for the United States Department of Energy by Sandia Corporation.

NOTICE: This report was prepared as an account of work sponsored by an agency of the United States Government. Neither the United States Government nor any agency thereof, nor any of their employees, nor any of their contractors, subcontractors, or their employees, makes any warranty, express or implied, or assumes any legal liability or responsibility for the accuracy, completeness, or usefulness of any information, apparatus, product, or process disclosed, or represents that its use would not infringe privately owned rights. Reference herein to any specific commercial product, process, or service by trade name, trademark, manufacturer, or otherwise, does not necessarily constitute or imply its endorsement, recommendation, or favoring by the United States Government, any agency thereof or any of their contractors or subcontractors. The views and opinions expressed herein do not necessarily state or reflect those of the United States Government, any agency thereof or any of their contractors.

Printed in the United States of America. This report has been reproduced directly from the best available copy.

Available to DOE and DOE contractors from

Office of Scientific and Technical Information

PO Box 62

Oak Ridge, TN 37831

Prices available from (615) 576-8401, FTS 626-8401

Available to the public from

National Technical Information Service

US Department of Commerce

5285 Port Royal Rd

Springfield, VA 22161

NTIS price codes

Printed copy: A03

Microfiche copy: A01 


\title{
Ceramic Powder Synthesis in Supercritical Fluids
}

\author{
C. L. J. Adkins and E. M. Russick \\ Organic Materials Processing \\ J. Cesarano and M. E. Tadros \\ Ceramic Processing Science \\ J. A. Voigt \\ Ceramic Synthesis and Inorganic Chemistry \\ Sandia National Laboratories \\ Albuquerque, NM 87185
}

\begin{abstract}
This report presents the results of a feasibility study performed in order to investigate the use of supercritical fluids to synthesize ceramics. Two approaches were taken. A small batch high pressure carbon dioxide reactor was built. In this reactor it was found that oxide ceramics can by synthesized in a supercritical carbon dioxide $\left(\mathrm{SCCO}_{2}\right)$ environment if surfactants are used to stabilize the reactants. The presence of the $\mathrm{SCCO}_{2}$ soluble surfactant is critical to the process. A spherical, polydisperse (diameters $\leq 1$ micron) titanium dioxide powder was synthesized in $\mathrm{SCCO}_{2}$ using titanium isopropoxide and water. The advantages of working in carbon dioxide, versus supercritical water, include mild pressures and temperatures, a less corrosive environment, and, in general, a safer, simpler system. As an alternative approach, a continuous flow, high pressure water reactor was built. Temperature control and equipment maintenance on this system proved very difficult.
\end{abstract}


Intentionally left blank. 


\section{Contents}

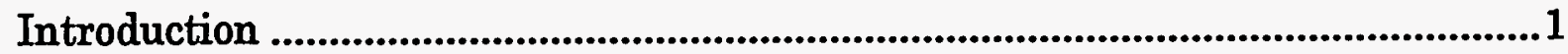

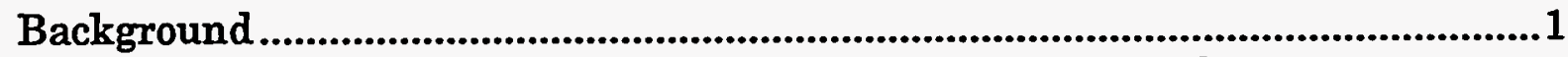

Synthesis of Titanium Dioxide Using the Reverse Micelle Technique ..................5

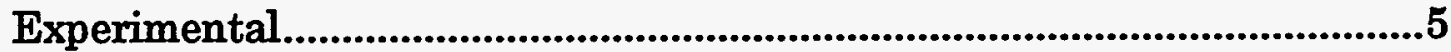

Control Experiments.....................................................................................6

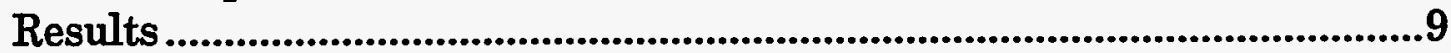

Conclusions ...........................................................................................................12

Powder Synthesis in a Continuous Hydrothermal/Supercritical

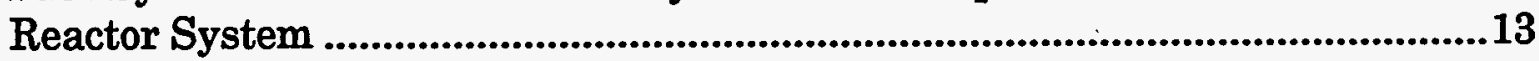

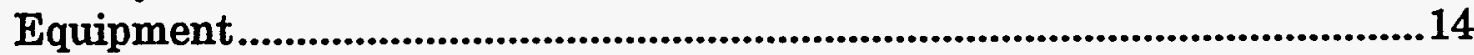

Reactor/Flowrate Temperature Calibration ....................................................16

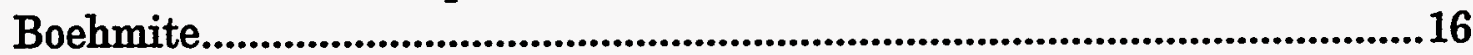

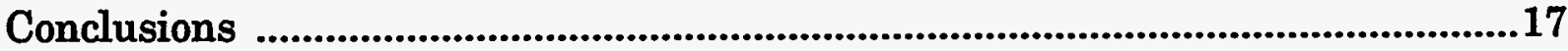

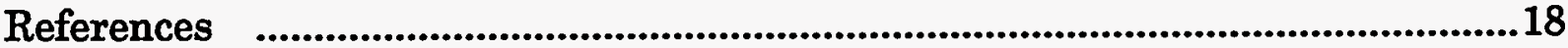

Figures

1 The Physical Processes by Which an Aerosol Forms and Grows by Thermal Decomposition/Reaction..................................................................... 3

2 Rapid Expansion of a Supercritical Fluid Through a Nozzle ....................... 3

3 Static $\mathrm{CO}_{2}$ Reverse Micelle Reactor ............................................................6

$4 \quad$ View Cell Apparatus for Solubility Measurements..................................... 7

$5 \quad$ Schematic of Reaction Medium ................................................................ 8

6 Silver Chloride Particles Prepared from Aqueous Solutions of AgNOs and $\mathrm{NaCl}$ with Zonyl FSJ Surfactant .............................................................. 8

7 SEM of Titanium Dioxide Particles Prepared from Ti[OCH(CHs $\left.)_{2}\right]_{4}$, and an Aqueous Solution of Zonyl FSJ in $\mathrm{SCCO}_{2}$........................................ 9

8 X-ray Diffraction Pattern of Titanium Dioxide Powder Prepared Using Reverse Micelle Technique .......................................................................... 10

9 TGA/DTA Results for Titanium Dioxide Powder Prepared in $\mathrm{SCCO}_{2}$....... 11

10 SEM of Titanium Dioxide Prepared by Hydrolysis of Ti[OCH( $\left.\left(\mathrm{CH}_{3}\right)_{2}\right]_{4}$ in a Mixture of Pentanol and Zonyl FSJ............................................................ 11

11 SEM of Titanium Dioxide Particles Prepared from Ti[OCH $\left.{ }_{2} \mathrm{CH}\left(\mathrm{C}_{2} \mathrm{H}_{5}\right)\left(\mathrm{CH}_{2}\right) \mathrm{CH}_{3}\right]_{4}$ and an Aqueous Solution of Zonyl FSJ

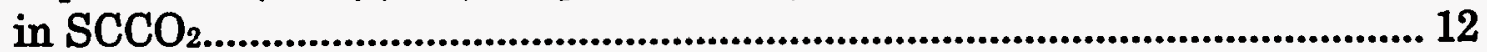

12 Continuous Hydrothermal/Supercritical Reactor System Schematic ........ 14

\section{Tables}

$1 \quad$ Critical Properties of Common Fluids.......................................................... 2

$2 \quad$ Solubility Data for Metal Alkoxides at $40^{\circ} \mathrm{C}$.................................................. 13

3 Temperature-Flowrate Characteristics of the Flow Reactor System .......... 17 


\section{Ceramic Powder Synthesis in Supercritical Fluids}

\section{Introduction}

Today, gas-phase processing plays an important role in the commercial production of a number of ceramic powders. ${ }^{1}$ These include titanium dioxide, carbon black, zinc oxide, and silicon dioxide. The total annual output of these materials is on the order of 2 million tons. ${ }^{1}$ The physical processes involved in gas-phase synthesis are typical of those involved in solution-phase synthesis ... chemical reaction kinetics, mass transfer, nucleation, coagulation, and condensation.

Since the phenomena associated with ceramic processing begin with preparation of the starting powder, new techniques and methods for synthesizing high-purity, non-agglomerated, well-characterized, submicron powders having a narrow size distribution are constantly being sought. Indeed, advanced material synthesis and innovative aerosol processes have been singled out as areas requiring additional research in powder synthesis. " "Gas-phase" synthesis methods (non-liquid) offer a number of benefits in the production of ceramic powders. These are: (1) direct formation of the particulate -.- calcining is not generally required as a separate step; (2) complex oxide formation is possible; (3) intimate mixing of the components; (4) high purity; (5) size distribution control; and (6) waste minimization. Perhaps the greatest disadvantages to gas-phase synthesis are the difficulty of the processes and their control, and lack of a full understanding of the relationship between the physical processes involved and their impact on the resulting product powder morphology.

This report will focus on the work done under a Laboratory-Directed Research and Development (LDRD) project that explored the use of various high pressure techniques for ceramic powder synthesis. Under this project, two approaches were taken. First, a continuous flow, high pressure water reactor was built and studied for powder synthesis. And second, a supercritical carbon dioxide static reactor, which was used in conjunction with surfactants, was built and used to generate oxide powders.

\section{Background}

A supercritical fluid is defined as a material above its critical temperature and critical pressure (see Table 1). Consequently, these fluids are not in the 
"gas-phase", although they are characterized by "gas-like" transport properties and "liquid-like" densities. They also offer a greatly enhanced solvating capability when compared to gases. Recently, the use of supercritical fluids has been applied to the generation of ceramic powders..$^{3.5}$ Reactions in the supercritical phase can lead to the nucleation of particles or the rapid expansion of a supercritical fluid can result in the particle formation. ${ }^{3,4}$ As the pressure is reduced, the solubility of the solute decreases and supersaturation occurs. Stable nuclei are formed and coagulation and condensation result in particle growth. The process is much like that which occurs in a vapor precursor/thermal decomposition particle formation process. The advantages of high pressure processes include: (1) waste minimization since the process fluid is recyclable; (2) submicron powder formation; and (3) "nonequilibrium" products as a result of the rapid particle formation in the rapid expansion technique.

Disadvantages include: (1) the high pressure operation; and (2) a general lack of information and understanding about the behavior of supercritical fluids.

\section{Table 1. Critical Properties of Common Fluids}

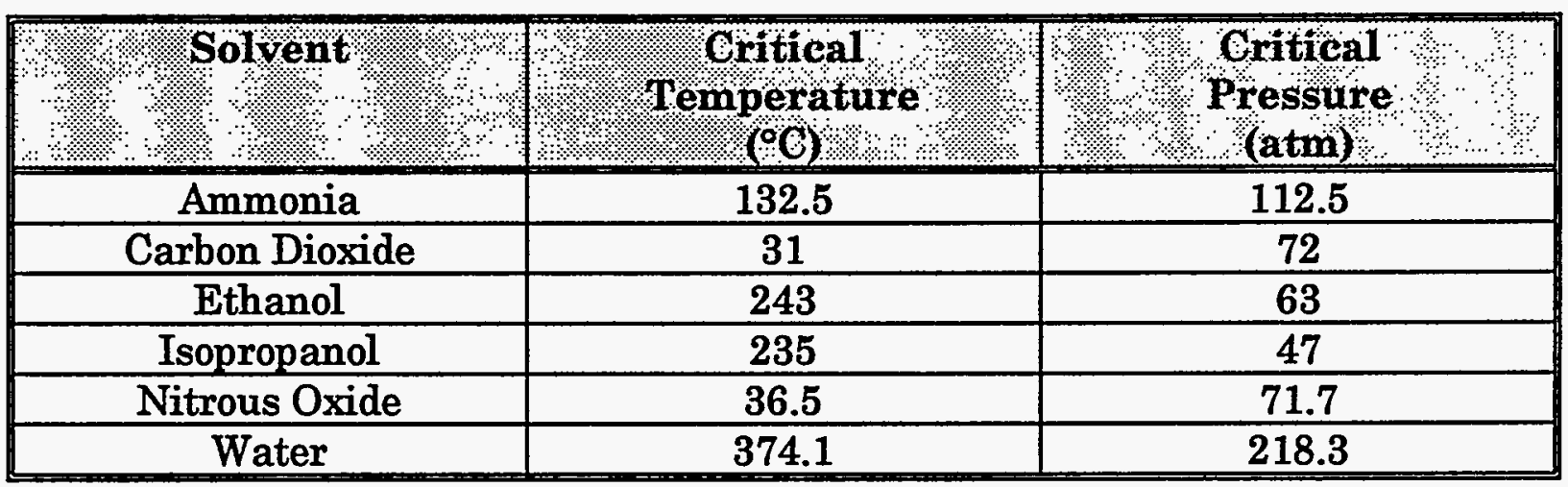

A schematic of a generic process whereby particles are nucleated under constant pressure conditions is presented in Figure 1. The sequence of events is similar whether particle formation occurs under atmospheric or high pressure conditions. The rapid expansion process is schematically described in Figure 2. The working fluid is compressed to a supercritical condition and flows to a vessel containing the bulk material that is to be dissolved. Solute-rich fluid flows to a collection chamber where it is allowed to expand through a nozzle. The gaseous working fluid passes out of the chamber. In the laboratory the gas is typically vented, although it could easily be recycled. The point at which particle formation actually occurs is still a subject of debate.

Matson et al. ${ }^{4}$ have used the rapid expansion technique to produce silica powders from supercritical water. The solubility of silica in water at $500^{\circ} \mathrm{C}$ and $1000 \mathrm{~atm}$ is $2600 \mathrm{ppm} .^{3}$ It was found that the size of the product depended strongly on the silica concentration in the supercritical fluid prior to expansion. 


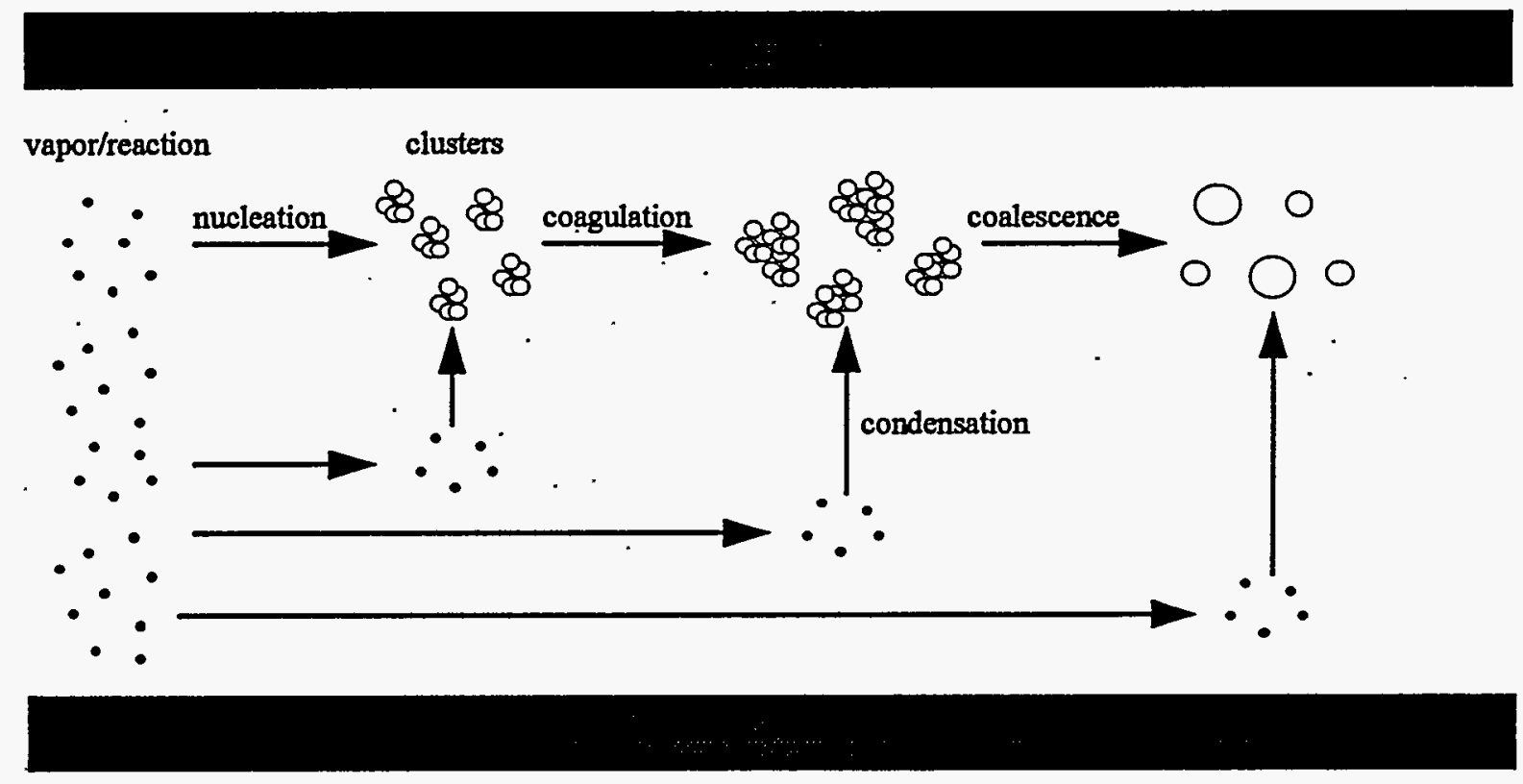

Figure 1. The Physical Processes by Which an Aerosol Forms and Grows by Thermal Decomposition/Reaction

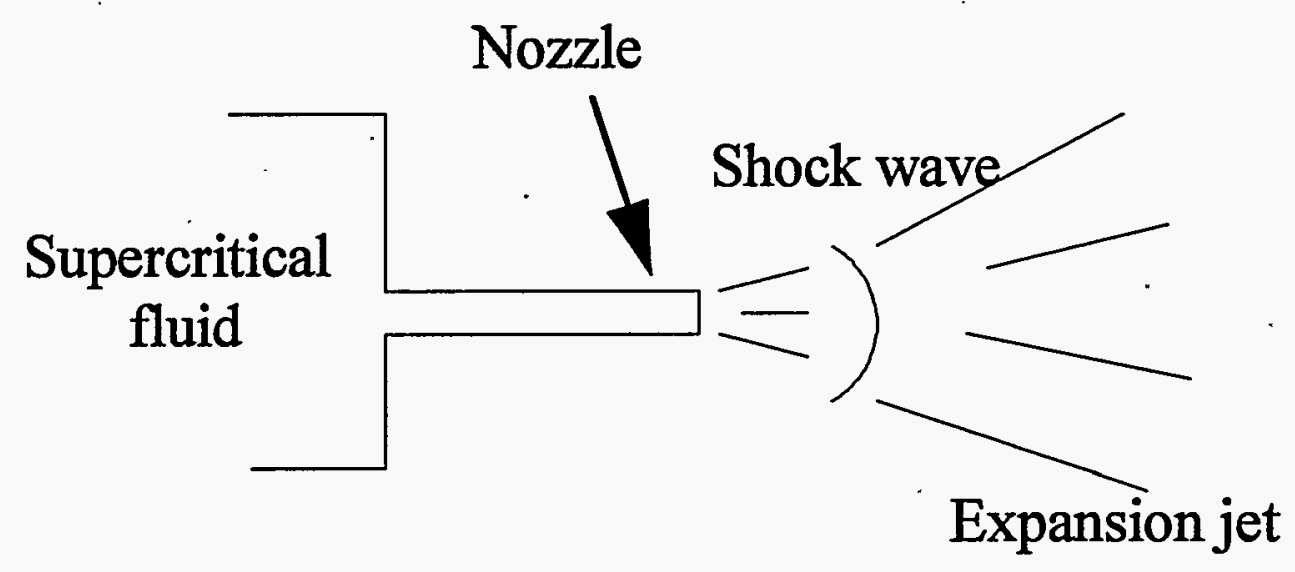

Figure 2. Rapid Expansion of a Supercritical Fluid 
Particle sizes ranged from 0.1 to $0.5 \mu \mathrm{m}$ in diameter. The morphology of the particles was found to depend on the nature of the expansion nozzle --- an orifice nozzle produced elongated particles while a capillary nozzle produced spheres. The difficulty with this particular process is that it is simply the regeneration of an already existing silica powder which is relatively insoluble in the working fluid. Germanium oxide $\left(\mathrm{GeO}_{2}\right)$ powder was also produced using a similar process. ${ }^{3}$

Pommier et al. ${ }^{5.7}$ produced spinel, $\mathrm{MgAl}_{2} \mathrm{O}_{4}$, powders in supercritical ethanol. In this case, the supercritical fluid served as a reactive medium as opposed to merely a carrier fluid. A $0.1 \mathrm{M}$ solution of the precursor material, $\mathrm{Mg}\left(\mathrm{Al}(\mathrm{OR})_{2}\right)_{4}$ where $R$ is a sec-butyl group, was charged into a high pressure reactor. The reactor was pressurized and heated. The vessel was then depressurized and the powders collected and dried. Primary particle sizes ranged from 0.04 to $0.2 \mu \mathrm{m}$, although due to agglomeration, the light scattering measurements indicated particle sizes on the order of several microns. Low levels of residual organic were detected after drying and the particles were approximately 10 to $30 \%$ crystalline. After annealing at $1000^{\circ} \mathrm{C}$ for an hour, complete crystallization was obtained. It is believed that simultaneous hydrolysis, polycondensation, and thermal decomposition reactions lead to powder formation.

In another investigation of high pressure ceramic synthesis, Adschiri et al. ${ }^{8}$ used metal salt -- nitrates, chlorides, etc. -- solutions as the metal oxide precursor materials. These solutions were fed to a continuous flow, high pressure water reactor where the temperature and pressure were increased to supercritical conditions. Hydrothermal crystallization of the powder occurred. The water-powder mixture was collected at the reactor outlet through the backpressure regulator. Reactor residence time was on the order of two minutes. The oxides were formed via hydrolysis of the salt to produce metal hydrous oxide, followed by dehydration. Small particles ( $<1$ micron) were formed. The inherent disadvantage of this technique -- reaction followed by controlled pressure let-down -- is that a water slurry of the product is collected and must be filtered and dried.

Finally, it is possible to use the supercritical fluid as a carrier solvent which does not participate in the reaction, but merely disperses the reactants. A "fluidphilic" surfactant can be used to form reverse micelles in which a water-soluble reactant is dispersed in the supercritical fluid. A second reactant, soluble in the supercritical fluid, diffuses into the micelle and reacts. From a powder production standpoint, one of the advantages of this technique is that each micelle acts as an individual reactor which is diffusion-limited. High diffusion rates may reduce the powder polydispersity and the pressure dependence of the 
fluid's behavior will facilitate particle separation. Also, the addition of surfactant allows the use of supercritical fluid's one does not expect to participate in the reactions. This technique was used by Matson et al. ${ }^{9}$ to form $\mathrm{Al}(\mathrm{OH})_{3}$ particles in supercritical propane. A surfactant was used to generate reverse micelles containing aqueous aluminum nitrate. The $\mathrm{Al}(\mathrm{OH})_{s}$ particles were precipitated upon the injection of ammonia. The mean particle size depended on the aluminum nitrate concentration in the micelles.

\section{Synthesis of Titanium Dioxide Using the Reverse Micelle Technique}

Supercritical carbon dioxide is an attractive medium for the synthesis of ceramic powders because it is nontoxic, nonflammable, has a low critical temperature, a high degree of compressibility, and low cost. However, the highly nonpolar character of $\mathrm{CO}_{2}$ limits the solubility of polar materials. ${ }^{10}$ In order to use $\mathrm{SCCO}_{2}$ as a reaction medium, it is necessary to use the reverse micelle technique described above. Hydrocarbon-based surfactants have limited solubility and are not useful for the stabilization of aqueous droplets in $\mathrm{SCCO}_{2}$. Surfactants with low solubility parameter moieties such as fluorocarbon or dimethyl siloxane groups are more soluble in $\mathrm{SCCO}_{2}{ }^{11 \cdot 14}$ and some of these surfactants have been shown to enable formation of reverse micelles and microemulsions in supercritical $\mathrm{CO}_{2}{ }^{12,13}$ The objective of this work is to investigate conditions for the synthesis of titanium dioxide particles from titanium alkoxides in supercritical $\mathrm{CO}_{2}$.

\section{Experimental}

Reagent grade titanium alkoxides were used without further purification. Zonyl FSJ (Du Pont) is a water soluble fluorinated anionic surfactant with the general formula $\left(\mathrm{F}\left(\mathrm{CF}_{2} \mathrm{CF}_{2}\right)_{z} \mathrm{CH}_{2} \mathrm{CH}_{2} \mathrm{O}\right)_{x} \mathrm{P}(\mathrm{O})\left(\mathrm{ONH}_{4}\right)_{y}$, where $\mathrm{x}=1$ or $2, \mathrm{y}=1$ or 2 , and $z=1-7$. This surfactant contains $15 \%$ isopropanol and $40 \%$ water. AerosolOT (Dow) is an anionic surfactant having the formula sodium bis(2-ethylhexyl) sulfosuccinate $\left(\mathrm{RO}_{2} \mathrm{CCH}_{2} \mathrm{CH}\left(\mathrm{SO}_{3} \mathrm{Na}\right) \mathrm{CO}_{2} \mathrm{R}, \mathrm{R}=\mathrm{CH}_{2}\left(\mathrm{CH}_{2}\right)_{3} \mathrm{CH}\left(\mathrm{C}_{2} \mathrm{H}_{5}\right) \mathrm{CH}_{2}-\right)$.

The reactions were performed in a $300 \mathrm{ml}$ Parr high pressure cell fitted with three $2.4 \mathrm{~cm}$ thick sapphire windows at right angles. Two Pyrex glass containers were placed inside the reactor. The glass containers were sufficiently tall to ensure that the rim of the containers was higher than the top portion of the viewing windows as shown in Figure 3. This configuration ensured that the contents of the two glass containers did not mix with each other upon filling the reactor with liquid $\mathrm{CO}_{2}$ to within the viewing level. 
The general experimental procedure was as follows. The metal alkoxide was placed in one of the Pyrex containers and an aqueous solution of surfactant was placed in the other Pyrex container. The reactor was then flushed and filled with liquid $\mathrm{CO}_{2}$ at $15^{\circ} \mathrm{C}$ to a level corresponding to the top portion of the viewing windows $(\sim 110 \mathrm{ml})$. The contents of the containers were each individually stirred by magnetic bars and a magnetic stirrer. The reactor was then heated to the desired temperature for a specified time, cooled to $20^{\circ} \mathrm{C}$, vented, and opened. Particles were collected and examined by SEM, X-ray diffraction, and thermal analyses.

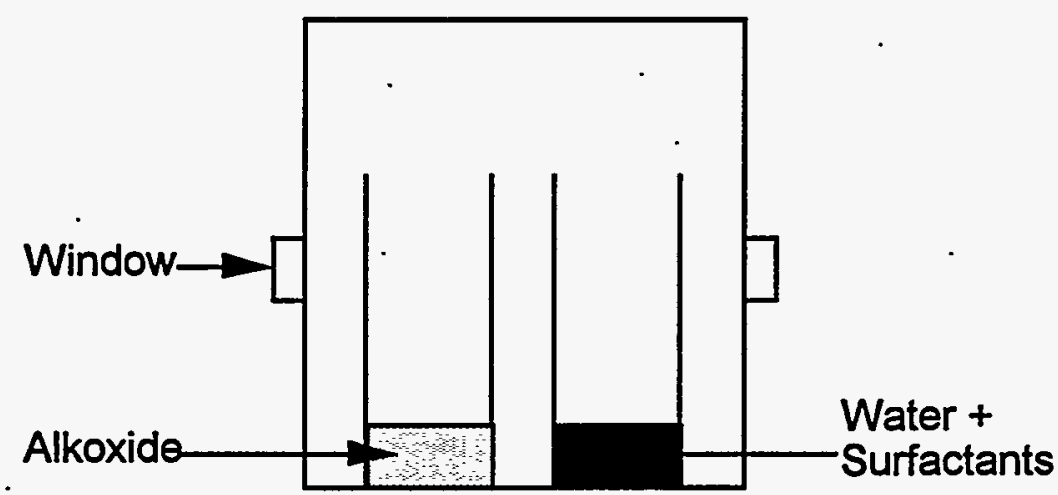

Figure 3. Static $\mathrm{CO}_{2}$ Reverse Micelle Reactor

The solubility of various metal alkoxides in supercritical $\mathrm{CO}_{2}$ was measured in a high pressure view cell. A schematic of this apparatus is shown in Figure 4. A high pressure "syringe" was used to vary the volume and pressure. A sapphire window allows viewing of the mixture by a fiber optic boroscope. The entire system was placed in a thermostated chamber. All solubility experiments were carried out at $40.0 \pm 0.1^{\circ} \mathrm{C}$. Given amounts of an alkoxide and $\mathrm{CO}_{2}$ were weighed into the cell which was then heated and stirred. The pressure was increased until a homogeneous phase was observed. The pressure was then decreased slowly until a "dew point" was observed, corresponding to conditions for phase separation of the alkoxide from the $\mathrm{CO}_{2}$. This can be interpreted two ways. First, at $40^{\circ} \mathrm{C}$ and all pressures greater than the dew point, this amount of alkoxide is soluble in the $\mathrm{SCCO}_{2}$. Or second, at $40^{\circ} \mathrm{C}$ and the dew point pressure, the alkoxide is soluble up to this concentration.

\section{Control Experiments}

In order to form a metal oxide in this apparatus, the following had to be true. First, the surfactant was soluble in $\mathrm{SCCO}_{2}$. Second, the surfactant would form reverse micelles containing water in the $\mathrm{SCCO}_{2}$. And third, the metal alkoxide was soluble in the $\mathrm{SCCO}_{2}$ (see Figure 5). In order to verify the first and second points -- that the surfactant would stabilize an aqueous dispersion in $\mathrm{SCCO}_{2}-$ a series of control experiments were performed. 
An aqueous solution of silver nitrate $\left(\mathrm{AgNO}_{3}\right)$ and a surfactant was placed in one of the glass containers and an aqueous solution of sodium chloride $(\mathrm{NaCl})$ and the same surfactant was placed in the other. The reactor was charged with $\mathrm{CO}_{2}$ and heated as usual. The results indicated that when no surfactant, or when Aerosol-OT was used, no AgCl precipitate was observed. Clearly, no mixing occurred between the solutions in the supercritical $\mathrm{CO}_{2}$ phase under these conditions. However, when the fluorinated surfactant Zonyl FSJ was used, fine particles of $\mathrm{AgCl}$ were obtained (see Figure 6). Zonyl FSJ is soluble in $\mathrm{CO}_{2}$ and carries the aqueous solutions into contact with each other. These particles are similar to particles prepared by the direct mixing of two microemulsion solutions, one containing $\mathrm{AgNO}_{3}$ and the other containing $\mathrm{NaCl}_{.}{ }^{15}$ In the past, dyes have been used to ascertain the formation of stable micelles and microemulsions in supercritical fluids ${ }^{12,16}$. The precipitation method adopted here is preferred over the dye solubility method because of the difficulties associated with observations through the reactor and potential interactions between the dye and carbonic acid, e.g., thymol blue is bleached in the presence of $\mathrm{CO}_{2}$ and water.

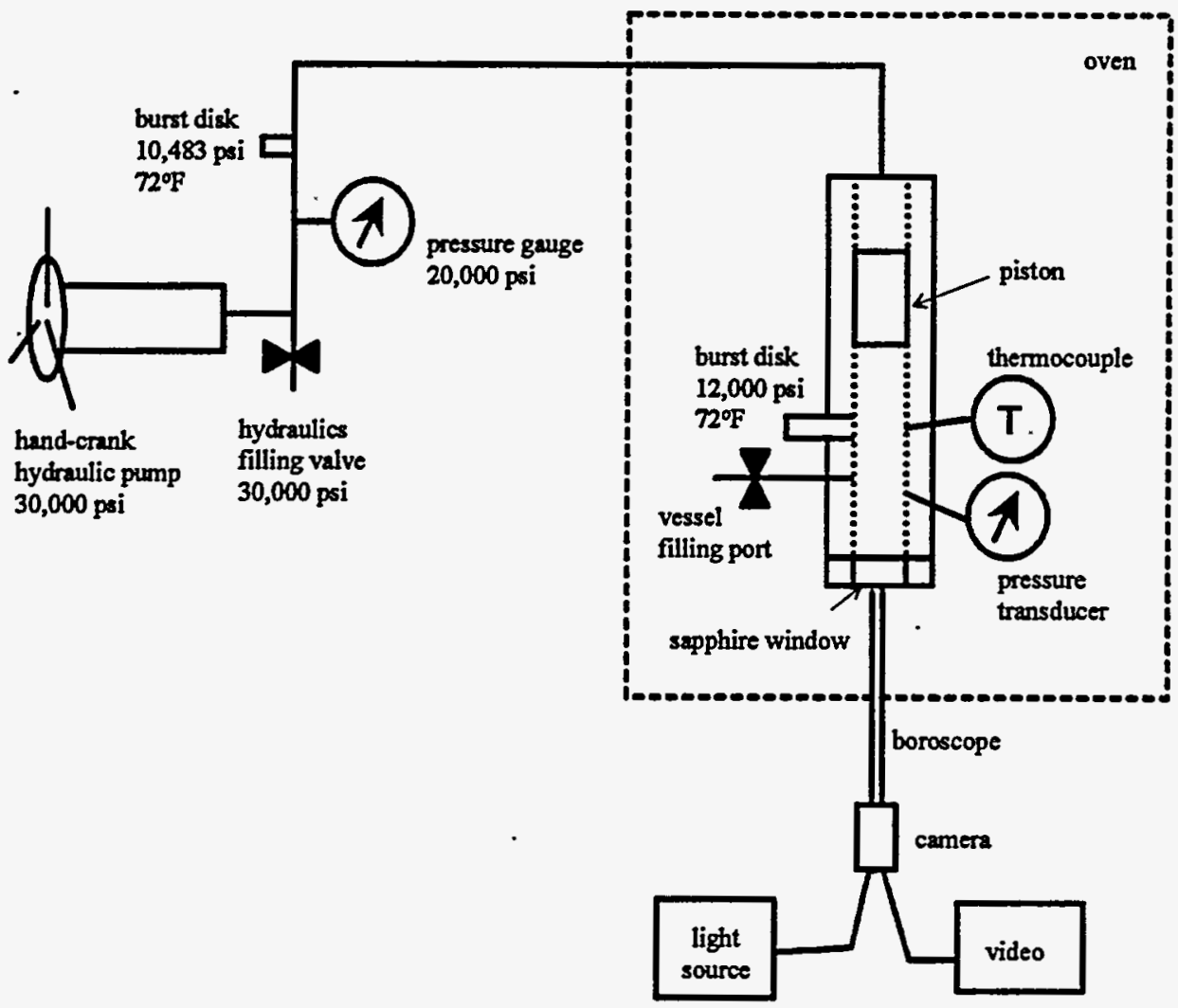

Figure 4. View Cell Apparatus for Solubility Measurements 


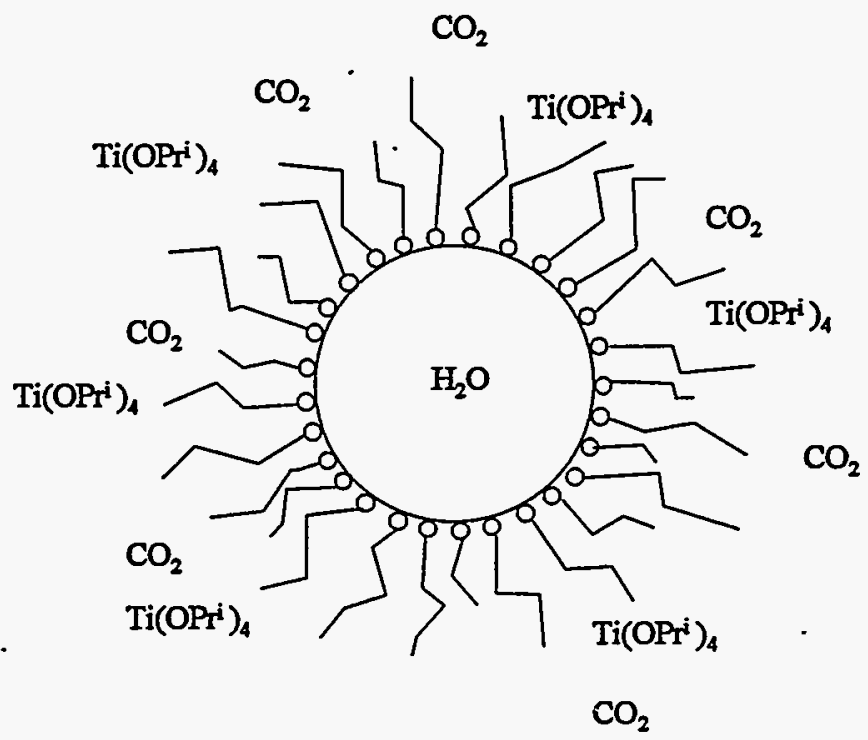

Figure 5. Schematic of Reaction Medium

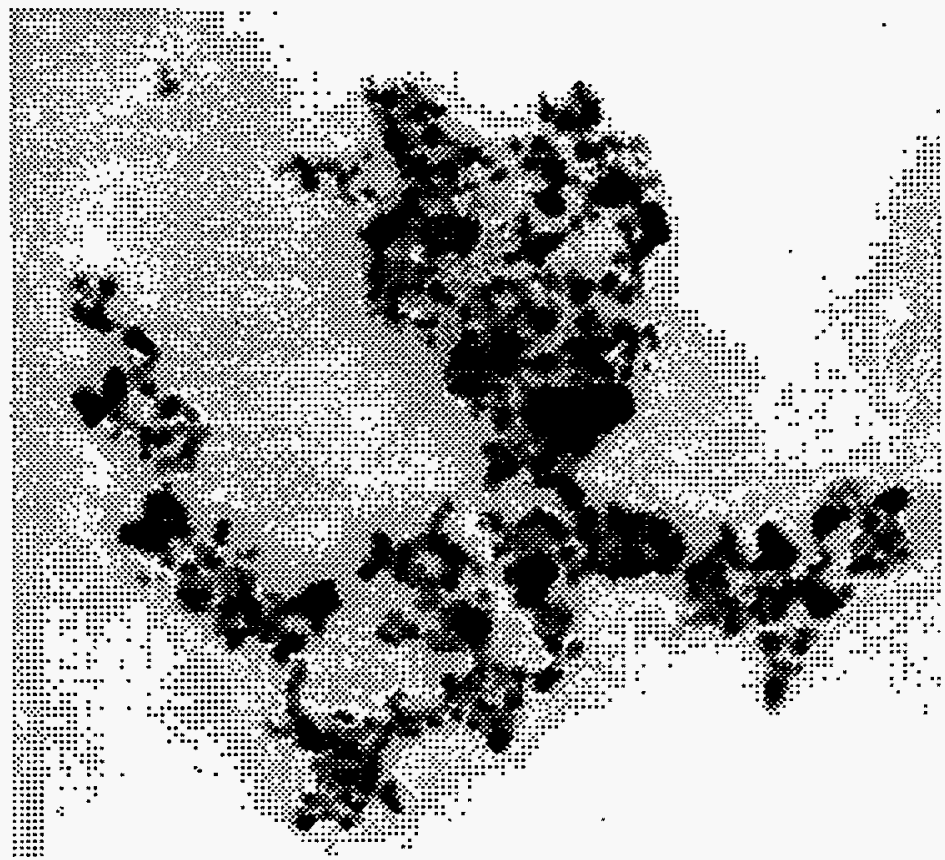

Figure 6. Silver Chloride Particles Prepared from Aqueous Solutions of $\mathrm{AgNO}_{3}$ and $\mathrm{NaCl}$ with Zonyl FSJ Surfactant. (Magnification: 1,386,000 x) 
A second control experiment was carried out in which water was placed in one of the Pyrex containers and titanium(IV) isopropoxide, Ti[OCH( $\left.\left(\mathrm{CH}_{3}\right)_{2}\right]_{4}$, in the other container. No surfactant was used. The reactor was charged with $\mathrm{CO}_{2}$ and heated to $50^{\circ} \mathrm{C}$ for 4 hours. No particles were observed on the walls of the reactor, although a small amount of precipitate was observed in the water container due to diffusion of some of the soluble titanium(IV) isopropoxide in the $\mathrm{SCCO}_{2}$. For effective powder generation, it is necessary to bring both reactants together in the supercritical phase.

\section{Results}

In a typical experiment, $2.0 \mathrm{~g}$ of titanium(IV) isopropoxide are placed in one of the Pyrex containers and $1.0 \mathrm{~g}$ of water and $2.0 \mathrm{~g}$ of Zonyl FSJ were mixed and placed in the other container. The reactor was heated to $50^{\circ} \mathrm{C}$ for $4 \mathrm{hrs}$. A white powder was observed covering the walls of the reactor and the glass containers. Scanning electron microscopy (SEM) indicated the formation of a polydisperse, spherical powder in the 0.1- 2 micron range (see Figure 7). X-ray diffraction showed the particles to be poorly crystalline anatase (see Figure 8).

Thermogravimetric and differential thermal analyses were used to study the weight loss and crystallization behavior of the powders. Typical results are depicted in Figure 9. The powder lost about $10 \%$ of its weight endothermically between 25 and $200^{\circ} \mathrm{C}$. An additional $18 \%$ weight loss occurs between 200 and $300^{\circ} \mathrm{C}$. The two exothermic peaks that appear at about 300 and $500^{\circ} \mathrm{C}$ correspond to the crystallization of anatase and rutile, respectively.

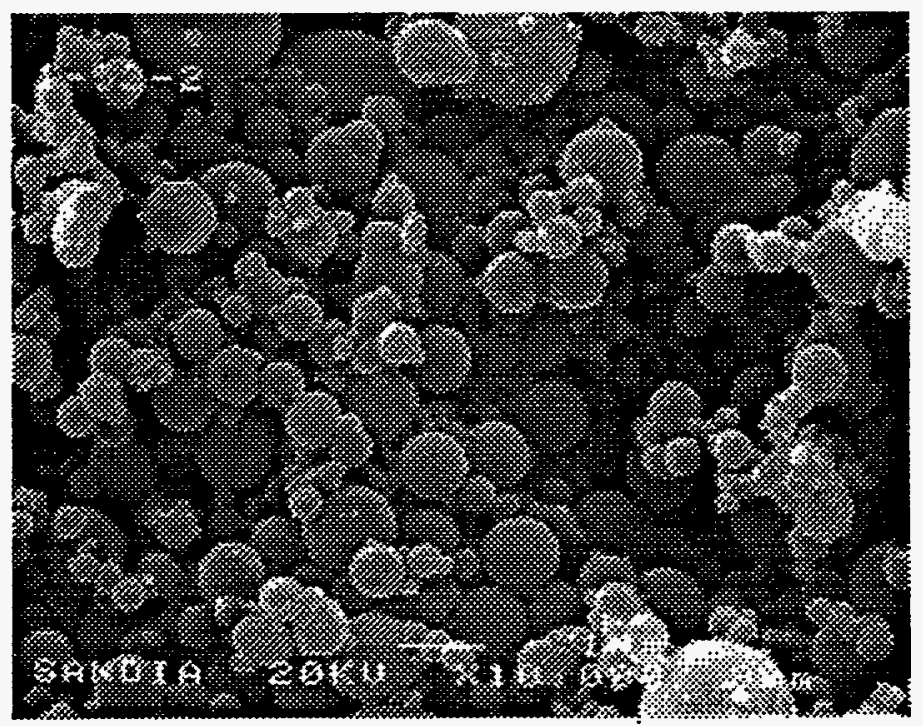

Figure 7. SEM of Titanium Dioxide Particles Prepared from Ti[OCH( $\left.\left(\mathrm{CH}_{3}\right)_{2}\right]_{4}$, and an Aqueous Solution of Zonyl FSJ in $\mathrm{SCCO}_{2}$. (Magnification: $10,000 \mathrm{x}$ ) 
A comparison of particles formed in the supercritical $\mathrm{CO}_{2}$ environment and particles formed by hydrolysis of titanium(IV) isopropoxide in a mixture of pentanol, Zonyl FSJ, and a small amount of water was carried out. Figure 10 shows that the particles formed in pentanol were not spherical.

A variety of experiments were carried out in the supercritical fluid reactor in the temperature range of $50-95^{\circ} \mathrm{C}$ and pressure range of $100-184 \mathrm{~atm}$. The products obtained were similar to those shown in Figure 7.

Other titanium alkoxides were tested. In the case of titanium(IV) ethoxide $\left(\mathrm{Ti}\left(\mathrm{OC}_{2} \mathrm{H}_{5}\right)_{4}\right)$ the particles obtained were similar to those obtained using titanium(IV) isopropoxide. On the other hand, titanium(IV) butoxide (Ti[O $\left.\left.\left(\mathrm{CH}_{2}\right)_{3} \mathrm{CH}_{3}\right]_{4}\right)$, titanium(IV) 2-ethylhexoxide (Ti[OCH $\left.{ }_{2} \mathrm{CH}\left(\mathrm{C}_{2} \mathrm{H}_{5}\right)\left(\mathrm{CH}_{2}\right)_{3} \mathrm{CH}_{3}\right]_{4}$ ), or aluminum tri-sec-butoxide ( $\left.\mathrm{Al}\left[\mathrm{OCH}\left(\mathrm{CH}_{3}\right) \mathrm{C}_{2} \mathrm{H}_{5}\right]_{3}\right)$, did not result in formation of spherical particles. Instead a mass of irregularly shaped particles was formed in the alkoxide container (see Figure 11). Solubility measurements were made for these alkoxides in supercritical $\mathrm{CO}_{2}$ at $40.0 \pm 0.1^{\circ} \mathrm{C}$ using the view cell. These data are given in Table 2. Again, it is important to remember that to uniquely define a supercritical fluid, both temperature and pressure must be specified and the solubilities in Table 2 represent the maximum alkoxide that will dissolve at $40^{\circ} \mathrm{C}$ and the pressure listed.

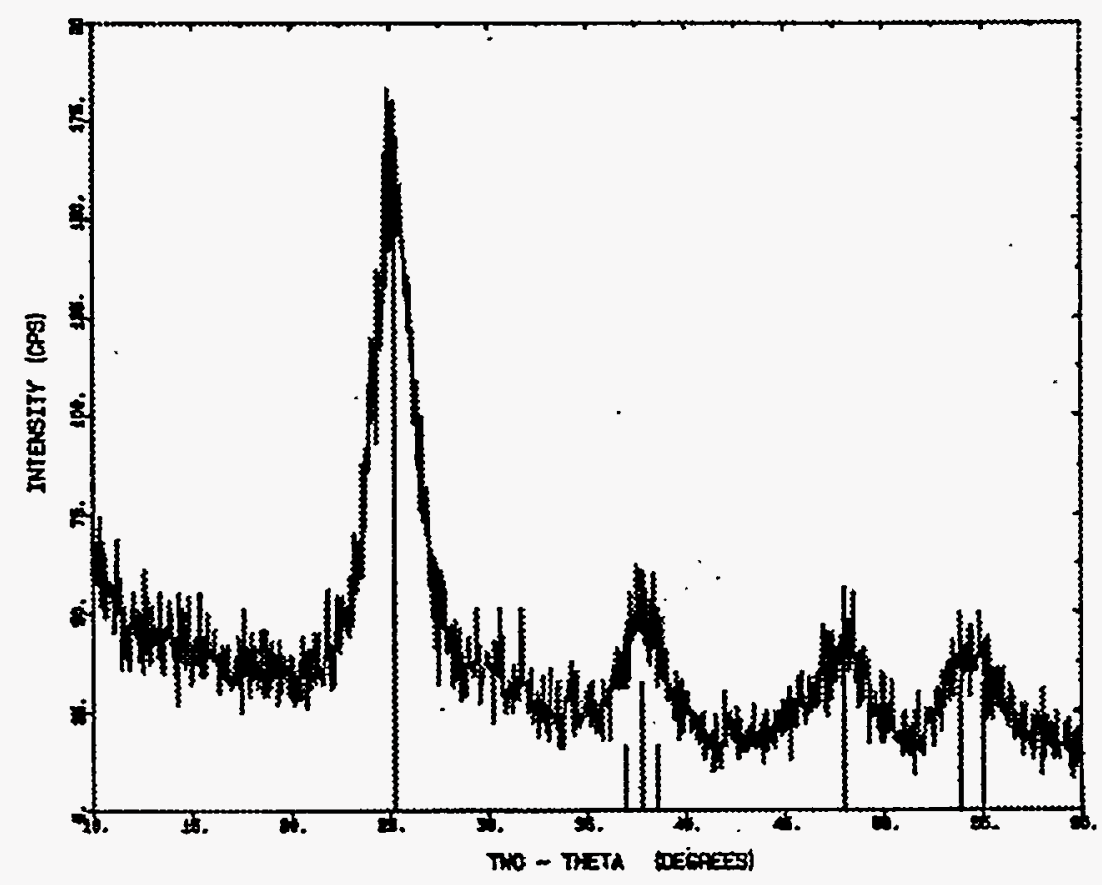

Figure 8. X-ray Diffraction Pattern of Titanium Dioxide Powder Prepared Using Reverse Micelle Technique 


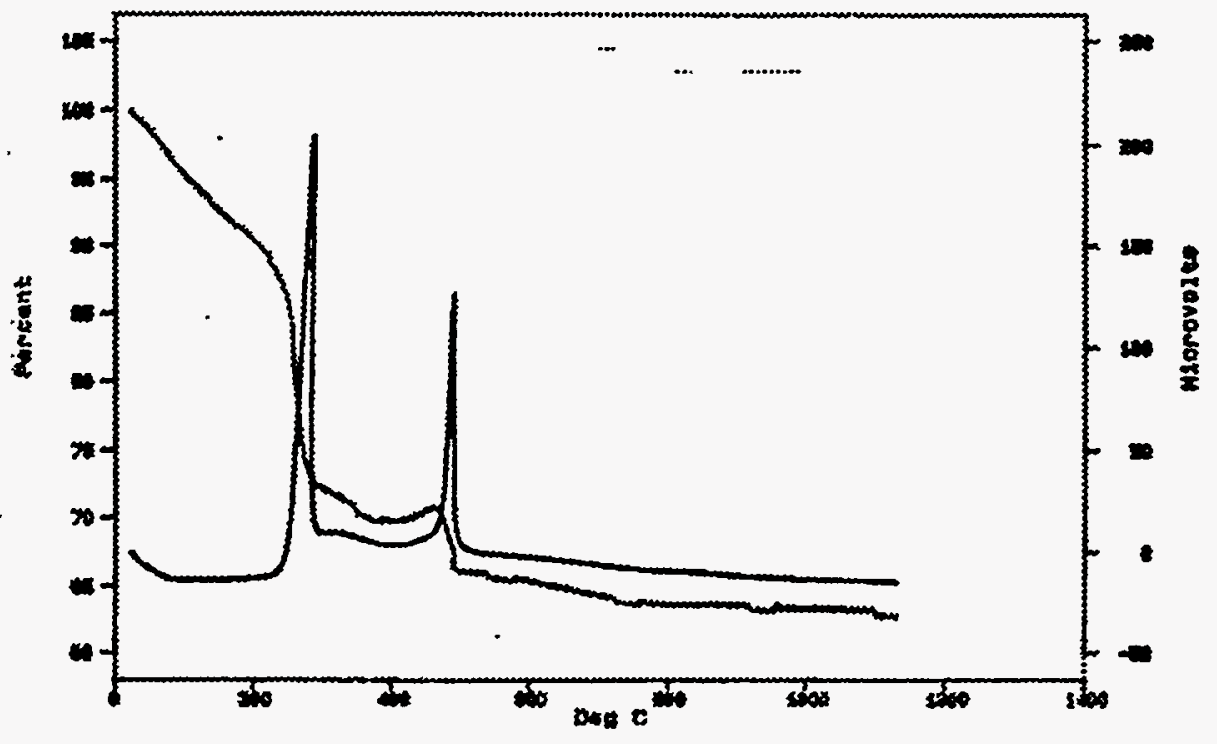

Figure 9. TGA/DTA Results for Titanium Dioxide Powder Prepared in $\mathrm{SCCO}_{2}$. $(10 \%$ min in air)

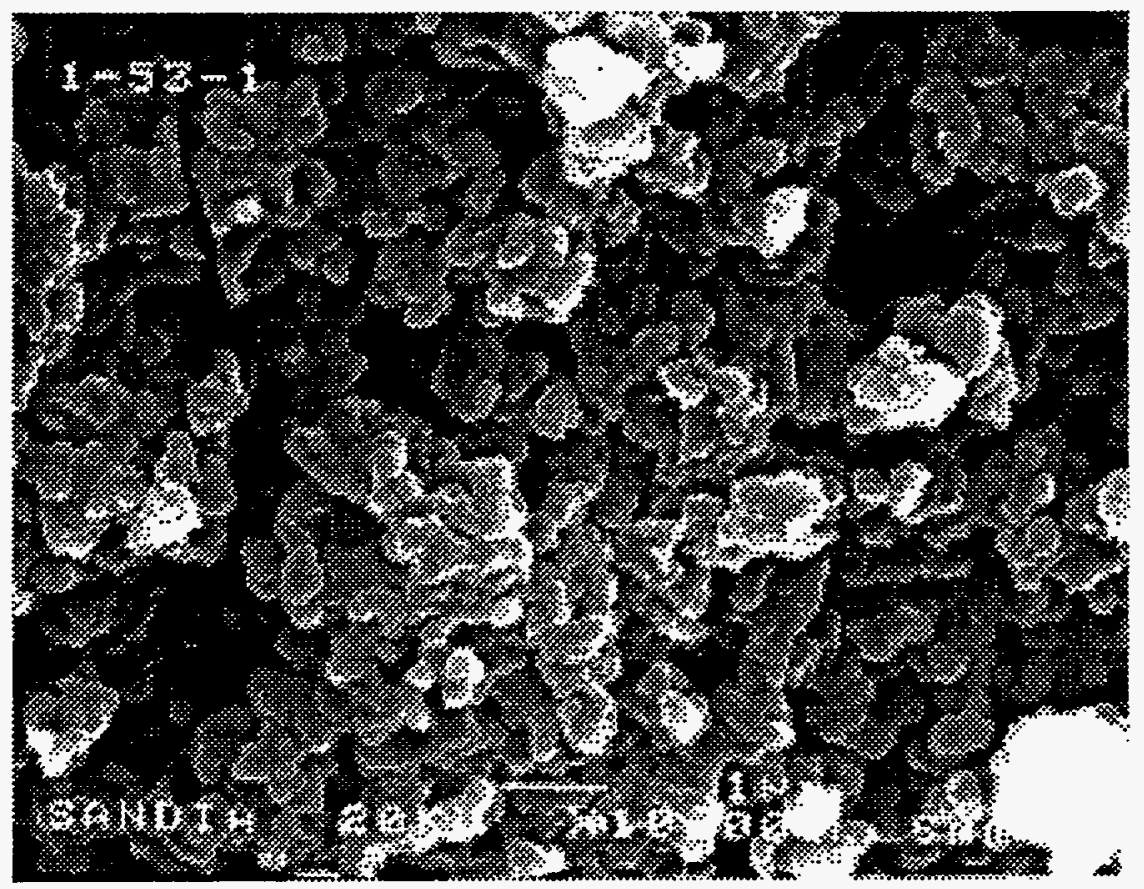

Figure 10. SEM of Titanium Dioxide Prepared by Hydrolysis of Ti[OCH( $\left.\left(\mathrm{CH}_{3}\right)_{2}\right]_{4}$ in a Mixture of Pentanol and Zonyl FSJ. (Magnification: 10,000 x) 


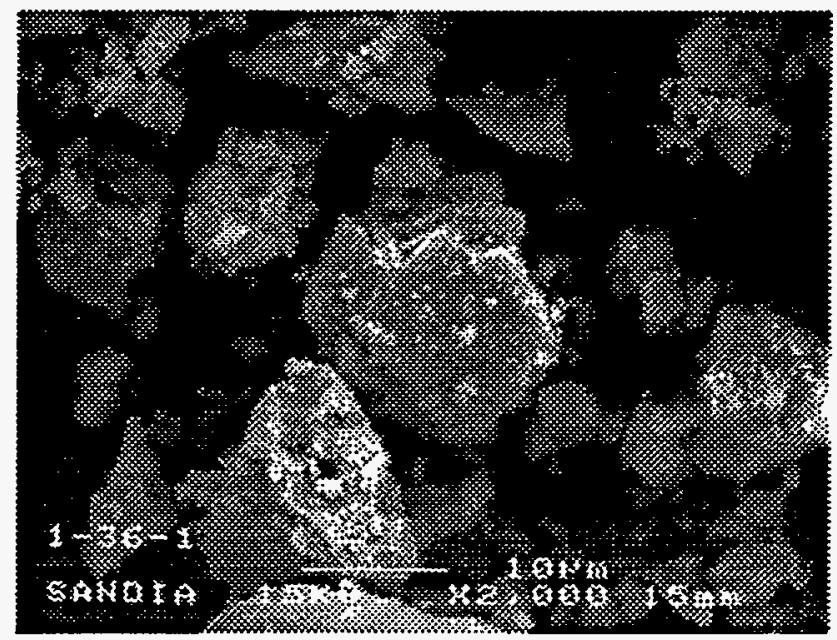

Figure 11. SEM of Titanium Dioxide Particles Prepared from Ti[OCH $\left.{ }_{2} \mathrm{CH}\left(\mathrm{C}_{2} \mathrm{H}_{5}\right)\left(\mathrm{CH}_{2}\right)_{3} \mathrm{CH}_{3}\right]_{4}$ and an Aqueous Solution of Zonyl FSJ in $\mathrm{SCCO}_{2}$.(Magnification: 2,000 x)

The solubility of these materials in $\mathrm{SCCO}_{2}$ loosely parallels the vapor pressure, decreasing as the vapor pressure decreases (as indicated by the boiling points). Titanium(IV) ethoxide is known to form polymeric species, tetrameric in the solid state and trimeric in benzene solutions. On the other hand, the sterically hindered titanium(IV) isopropoxide, $\operatorname{Ti}\left[\mathrm{OCH}\left(\mathrm{CH}_{3}\right)_{2}\right]_{4}$, is monomeric. This may account for its high solubility in $\mathrm{SCCO}_{2}$. Titanium(IV) butoxide and aluminum tri-sec-butoxide are also known to form oligomers in the unhydrolyzed states. Particle formation in the supercritical phase under the conditions employed is clearly dependent on the solubility of the alkoxide. If the alkoxide is not sufficiently soluble in the $\mathrm{SCCO}_{2}$, the surfactant-water mixture diffuses to the alkoxide to form particles at the interface, rather than particle formation occurring in the supercritical phase.

\section{Conclusions}

Spherical particles of titanium dioxide (anatase) were prepared in supercritical carbon dioxide from titanium alkoxides and water. The dissolution of the alkoxide and stabilization of water dispersions in supercritical $\mathrm{CO}_{2}$ were found to be critical for the formation of spherical particles. An anionic fluorinated surfactant which is soluble in $\mathrm{SCCO}_{2}$ was used to stabilize water dispersions in the supercritical phase. Use of a hydrocarbon-based surfactants, which are not soluble in $\mathrm{SCCO}_{2}$, did not result in particle formation. The solubility of the titanium alkoxide in the $\mathrm{SCCO}_{2}$ has a direct influence on particle formation and appears to parallel the vapor pressure, which is dependent on the oligomerization of the unhydrolyzed alkoxides. Polydispersity in particle sizes is due to nucleation occurring simultaneously with particle growth. 
Table 2. Solubility Data for Metal Alkoxides at $40^{\circ} \mathrm{C}$

\begin{tabular}{|c|c|c|c|}
\hline $\begin{array}{ccc}\text { Alkoxide } & \\
& & \end{array}$ & $\mathbf{P}(\mathbf{a t m})$ & $\begin{array}{l}\text { Solubility } \\
40^{\circ} \mathrm{C}, \mathrm{P} \\
\text { Weight } \%\end{array}$ & Boiling Point \\
\hline$\underset{\text { Titanium (IV) isopropoxide }}{\operatorname{Ti}}$ & 81 & . & $232^{\circ} \mathrm{C} @ 760 \mathrm{~mm}$ \\
\hline $\begin{array}{l}\mathrm{Ti}[\mathrm{O}-]_{4} \\
\text { Titanium (IV) ethoxide }\end{array}$ & 120 & 4.19 & $150^{\circ} \mathrm{C} @ 10 \mathrm{~mm}$ \\
\hline Titanium (IV) butoxide & 184 & 3.05 & $206^{\circ} \mathrm{C} @ 10 \mathrm{~mm}$ \\
\hline $\mathrm{Ti}[\mathrm{O} \longrightarrow]_{4}$ & 353 & 2.21 & $249^{\circ} \mathrm{C} @ 11 \mathrm{~mm}$ \\
\hline Al-o- $]_{3}$ & $>612$ & 6.13 & $200^{\circ} \mathrm{C} @ 30 \mathrm{~mm}$ \\
\hline
\end{tabular}

\section{Powder Synthesis in a Continuous Hydrothermal/Supercritical Reactor System}

The rapid expansion technique is extremely dependent on the flow characteristics of the expansion nozzle. In addition, for homogeneous nucleation to occur properly in the spray, there must be no particle formation in the supercritical phase prior to expansion -- otherwise condensation would be the primary mechanism of growth. Consequently, the focus in this project was 
placed on understanding particle formation (and therefore how to avoid it) in the supercritical phase reactor. Powder synthesis in the supercritical medium provides an opportunity to generate crystalline powders with controlled morphology and particle size distribution using a fundamental understanding of particle nucleation and growth kinetics and mechanisms. The long term goal of this effort is the development of a technique to produce "designer" powders with properties optimized for specific materials development projects. Indeed, a new project focusing on the formation of lead zirconate titanate powders for neutron generators has begun and this technique will be included.

The equipment necessary for exploring powder synthesis via rapid expansion is similar to that needed for powder synthesis via reaction in the supercritical phase. The cooling system (to chill the supercritical fluid to liquid conditions), back pressure regulator (for pressure let-down), and powder collection system can be replaced with a nozzle to convert the reaction synthesis system into a rapid expansion system provided that no particle generation occurs in the supercritical region. The apparatus, the temperature/flow rate characteristics of the system, the system operating procedure, and a test of the system in which boehmite (AlOOH) was prepared in supercritical water are discussed below for a reaction synthesis apparatus.

\section{Equipment}

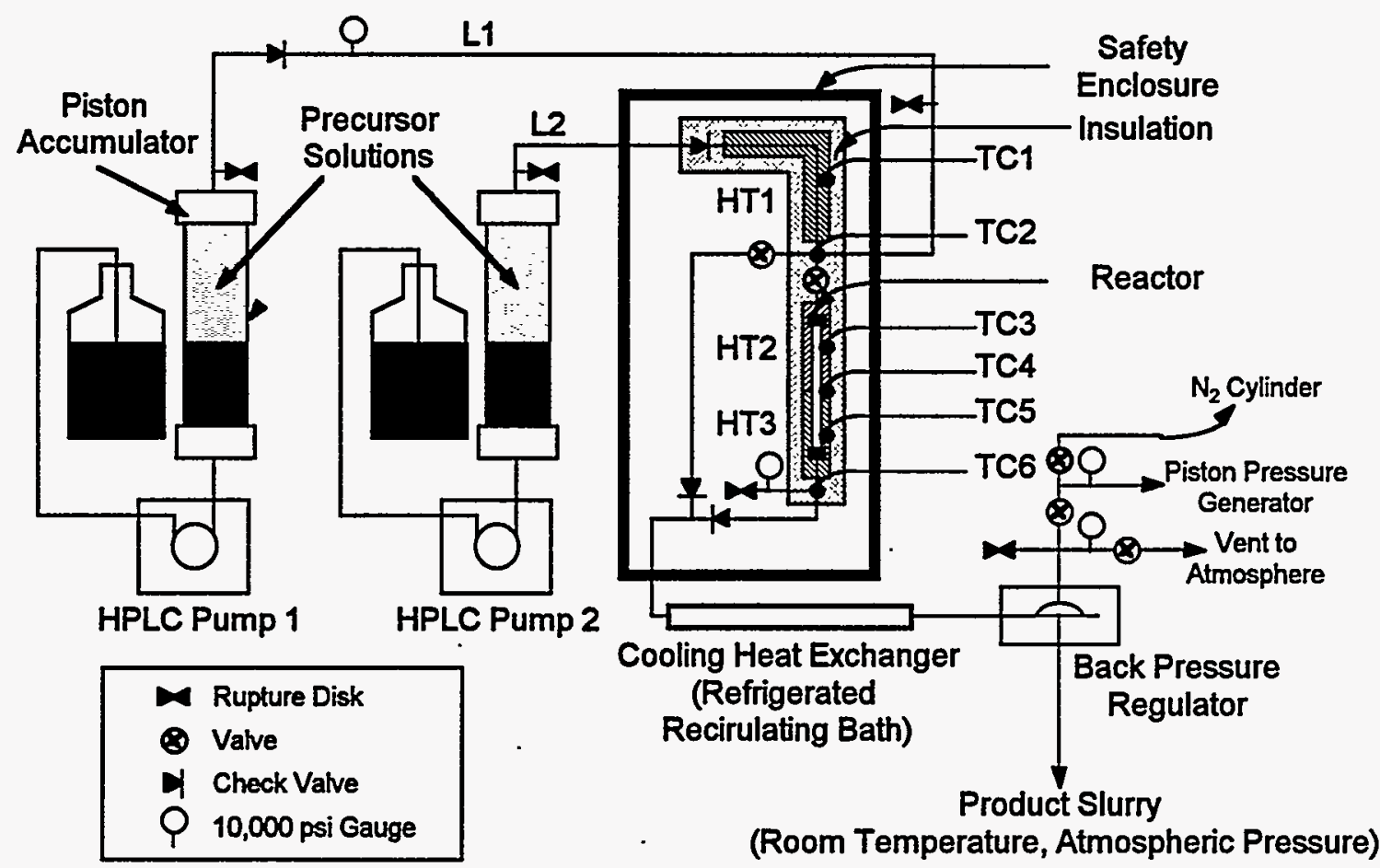

Figure 12. Continuous Hydrothermal/Supercritical Reactor System Schematic (TC = thermocouple, $\mathrm{HT}=$ heating tape, and $\mathrm{L}=$ reactant feed line) 
A bench-scale continuous hydrothermal/supercritical reactor system was designed and built. A schematic of the system is shown in Figure 12. This multipurpose system is capable of operating as a continuous laminar flow tubular reactor or as a stopped-flow reactor. The system was designed to process under conditions of up to $450^{\circ} \mathrm{C}$ in temperature and at pressures of up to $340 \mathrm{~atm}$. These operating conditions allow for solution processing of materials in an aqueous environment from single phase hydrothermal conditions up through the supercritical range. By replacing the output fitting of the tubular reactor with a orifice plate, the system can also be operated as a supercritical expansion reactor.

The system was constructed of $\mathbf{3 1 6}$ stainless steel with two reactant feed lines (L1 and L2), where the solutions were fed from two $500 \mathrm{ml}$ piston accumulators driven by HPLC pumps rated to $410 \mathrm{~atm}$. Basically, the feed systems are similar to having two large syringe pumps. The HPLC pumps provide highly accurate and constant flow rates regardless of system pressure. Feed L2 was fitted with a heating tape, H1, to preheat the stream before it is mixed with stream L1. The controlling thermocouple (T2) is positioned in the feed stream at the point where the two streams are mixed. This positioning of the controlling thermocouple proved to be the most efficient way of rapidly heating the two solutions to the desired temperature as they are mixed.

The tubular reactor used was 12 inches long. with an interior diameter of 0.197 inches and constructed of 316 stainless steel. Only in the reactor would the water be supercritical. Supercritical water is known to be highly corrosive and often more expensive alloys, e.g., Inconel, are used. However, it was felt that with monitoring, effective and safe use could be made of a stainless steel reactor based on the literature indicating that much work was being done in this area with stainless steel. The reactor section of the system was located as close to the feed stream mixing tee as the fittings would allow. Two heating tapes were used to control the reactor temperature (designated as $\mathrm{H} 2$ and $\mathrm{H} 3$ in Figure 12, referenced to thermocouples TC3 and TC5, respectively). The entire preheated section of $\mathrm{L} 2$ and the reactor were wrapped with insulation to help improve temperature uniformity. Because of the high thermal conductivity of the stainless steel, the feed from the reactor cooled rapidly. The reactor exit temperature of the product stream was monitored by an in-stream thermocouple (TC6) that was located as close to the exit port of the reactor as the fittings would allow. After leaving the reactor the product stream was cooled to room temperature by flowing chilled water through copper tubing that was wrapped around the tubing containing the product stream.

The pressure in the system was controlled by a back pressure regulator through which the product stream. was fed before it was vented to atmospheric 
pressure and collected. The back pressure regulator consisted of a diaphragm which opened when the system pressure exceeded that of the pressure set on the diaphragm side opposite of that where the product stream flowed. The procedure for operation of the reactor system is given in Appendix A.

\section{Reactor/Flowrate Temperature Calibration}

Much time was taken to insure that the two reactant feed streams could be rapidly and simultaneously mixed and heated to the desired temperature. This proved to be a difficult and time consuming task at the temperatures and pressures of interest $\left(350-450^{\circ} \mathrm{C}\right.$ and $\left.>200 \mathrm{~atm}\right)$. It was accomplished through the use of a mixing-tee configuration in which the controlling thermocouple of the heater for one of the reactant streams (L2) was placed in the tee. The set point temperature for this heater was set to the desired reaction temperature. This resulted in the heating this stream to temperatures greater than desired to compensate for the thermal energy required to heat the feed from the other reactant stream. Experiments wiere carried out to map out the temperature-feed flow rate space that is allowed based on the capacity of the heating elements. Table 3 shows the results of these experiments. In general it took between 10 and 20 minutes for the system to reach equilibrium when the temperature and/or the feed flow rates were changed. The results shown in the table illustrate two of the limitations of the system. For the $300^{\circ} \mathrm{C}$ set point and L1/L2 flow rate combinations of $0.1 / 0.9 \mathrm{ml} / \mathrm{min}$ and $0.5 / 4.5 \mathrm{ml} / \mathrm{min}$, the monitoring thermocouple at the center of the reactor zone (TC4) showed a temperature above that of the desired temperature. This indicates that too much thermal energy was being provided for this region of the reactor. With a higher total flow rate of $10 \mathrm{ml} / \mathrm{in}(\mathrm{L} 1 / \mathrm{L2}=1.0 / 9.0 \mathrm{ml} / \mathrm{min})$, a larger load on the heating tapes evened out the temperature distribution. The other limitation is shown in the $400^{\circ} \mathrm{C}$ and high total flow rate $(\mathrm{L} 1 / \mathrm{L} 2=1.0 / 9.0 \mathrm{ml} / \mathrm{min})$ data. For this case, the heating capacity of the tapes was exceeded and the system was not capable of reaching the desired system temperature. These limitations could be overcome with a more sophisticated heating and temperature control system.

\section{Application to Boehmite Synthesis}

The hydrolysis of aluminum salt solutions to form $\mathrm{AlOOH}$ (boehmite) precipitates was used as the test system for the reactor in its continuous reactor mode. The experiment was successfully completed producing the desired product. Unfortunately, during this experiment one of the HPLC pumps malfunctioned. Extensive delays in its repair by the manufacturer, prevented further experimentation. However, it was demonstrated that the system would operate under either hydrothermal or supercritical conditions. The equipment 
will be used in fundamental studies of lead zirconate titanate particle growth as part of a new project looking the solution synthesis of these materials for neutron generator applications.

Table 3. Temperature-Flowrate Characteristics of the Flow Reactor System (Pressure $=272 \mathrm{~atm}$ (water was used in L1 and L2))

\begin{tabular}{|c|c|c|c|c|c|c|c|c|}
\hline $\begin{array}{c}\text { Set } \\
\text { Temp } \\
\left({ }^{\circ} \mathrm{C}\right)\end{array}$ & \multicolumn{2}{|c|}{$\begin{array}{l}\text { Flowrate } \\
(\mathbf{m l} / \text { min) }\end{array}$} & \multicolumn{6}{|c|}{$\begin{array}{l}\text { Thermocouple Readings } \\
\quad\left({ }^{\circ} \mathrm{C}\right)\end{array}$} \\
\hline & L1 & L2 & TCI & TC2 & $\mathrm{TC3}$ & TC4 & TC5 & IC6 \\
\hline 300 & 0.1 & 0.9 & 277 & 299 & 300 & 327 & 302 & 72 \\
\hline 300 & 0.5 & 4.5 & 252 & 294 & 297 & 327 & 302 & 220 \\
\hline 300 & 1.0 & 9.0 & 299 & 300 & 299 & 298 & 303 & 264 \\
\hline 350 & 1 & 4 & 318 & 347 & 346 & 349 & 350 & 275 \\
\hline 350 & 2 & 3 & 352 & 351 & 351 & 355 & 351 & 248 \\
\hline 400 & 0.1 & 0.9 & 368 & 398 & 400 & 398 & 401 & 126 \\
\hline 400 & 0.5 & 4.5 & 389 & 397 & 396 & 392 & 399 & 325 \\
\hline 400 & 1 & 9 & 310 & 292 & 389 & 389 & 394 & 356 \\
\hline 400 & 1 & 4 & 403 & 397 & 399 & 393 & 399 & 351 \\
\hline
\end{tabular}

\section{Conclusions}

The continuous flow reactor was constructed first and based on the difficulty in establishing a constant temperature profile that was flowrate insensitive and the maintenance difficulties, it was decided that there is a distinct benefit to operating at the lower pressures and less corrosive conditions associated with carbon dioxide. The use of surfactants, provided they are soluble and form micelles in the supercritical fluid, greatly extends the regime in which carbon dioxide can be considered as a reaction medium. It was demonstrated that either the water continuous flow or carbon dioxide reverse micelle technique can be used to generate ceramic powders. The control and equipment is difficult to maintain in the high temperature, high pressure water system. The reverse micelle technique has definite advantages if the fluid of interest (for instance, ammonia) is not considered safe to work with in large quantities. Appropriate use of micelles would minimize the active fluid volume and potentially lead to the formation of non-oxide ceramics. 


\section{References}

1. P. Stamatakis, C. A. Natalie, B. R. Palmer and W.A. Yuill, Aerosol Sci. and Technol., 14(3), 316 (1991).

2. B. J. Ennis, J. Green and R. Davies, Chemical Engineering Prog., 90(4), 32 (1994).

3. D. W. Matson, R. C. Peterson and R. D. Smith, J. Matls. Sci., 22, 1919 (1987).

4. D. W. Matson, J. L. Fulton, R. C. Petersen and R. D. Smith, Ind. Engr. Chem. Res., 26, 2298.(1987).

5. C. Pommier, K. Chhor, J. F. Bocquet and M. Barj, Matl. Res. Bull., 25, 213 (1990).

6. M. Barj, J. F. Bocquet, K. Chhor, and C. J. Pommier, J. Matls. Sci., 27, 2187 (1992).

7. C. J. Pommier, K. Chhor, J. F. Bocquet and M. Barj, Ind. Ceram., Verriere, 881, 260 (1993).

8. T. Adschiri, K. Kanazawa and K. Arai, J. Amr. Ceramic Soc., 74(4), 1019 (1992).

9. D. W. Matson, J. L. Fulton, and R. D. Smith, Materials Letters, 6(1,2), 31 (1987).

10. K. A. Consani and R. D. Smith, J. Supercritical Fluids, 3, 51 (1990).

11. T. A. Hoefling, D. A. Newman, R. M. Enick and E. J. Beckman, J. Supercritical Fluids, 6, 165 (1993).

12. T. A. Hoefling, R. M. Enick and E. J. Beckman, J. Phys. Chem., 95, 7127 (1991).

13. J. M. DeSimone, E. E. Maury, Y. Z. Menceloglu, J. B. McClain and T. J. Romack, Science, 265, 356 (1994).

14. A. Tezzi, P. Bendale, R. M. Enick, M. Turberg, and Brady, Fluid Phase Equilibria, 52, 307 (1989).

15. M. Dvolaitzky, R. Ober, C. Taupin, A. Anthore, X. Auvray, C. Petipas and C. J. Williams, J. Dispersion Sci. Tech., 4, 29 (1983).

16. R. W. Gale, J. L. Fulton and R. D. Smith, J. Amr. Chem. Soc., 109, 920 (1987). 


\section{DISTRIBUTION:}

$\begin{array}{lrl}1 & \text { MS 0333 } & \text { A. J. Hurd, 1841 } \\ 1 & 0333 & \text { M. E. Tadros, 1841 } \\ 1 & 1349 & \text { J. Cesarano, 1841 } \\ 1 & 1407 & \text { J. H. Aubert, 1815 } \\ 1 & 0367 & \text { C. L. J. Adkins, 1815 } \\ 1 & 0367 & \text { E. M. Russick, 1815 } \\ 1 & 1405 & \text { J. A. Voigt, 1846 } \\ 1 & 1405 & \text { B. Hammetter, 1846 } \\ 1 & 1435 & \text { H. J. Saxton, 1800 } \\ 1 & 1436 & \text { C. Meyers, 1011 } \\ 1 & \mathbf{9 0 1 8} & \text { Central Technical Files, 8523-2 } \\ 5 & 0899 & \text { Technical Library, 4414 } \\ 1 & 0619 & \text { Print Media, 12615 } \\ 2 & 0100 & \text { Document Processing, 7613-2 } \\ & & \text { For DOE/OSTI }\end{array}$


